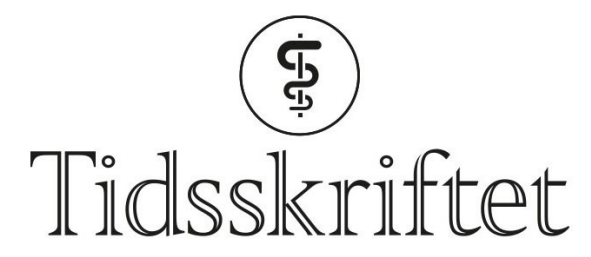

DEN NORSKE LEGEFORENING

\title{
Tyroksin kan også virke raskt
}

FRA ANDRE TIDSSKRIFTER

HAAKON B. BENESTAD

Universitetet i Oslo

Tyroksin virker på både cytoplasma og cellekjerne, viser musestudier.

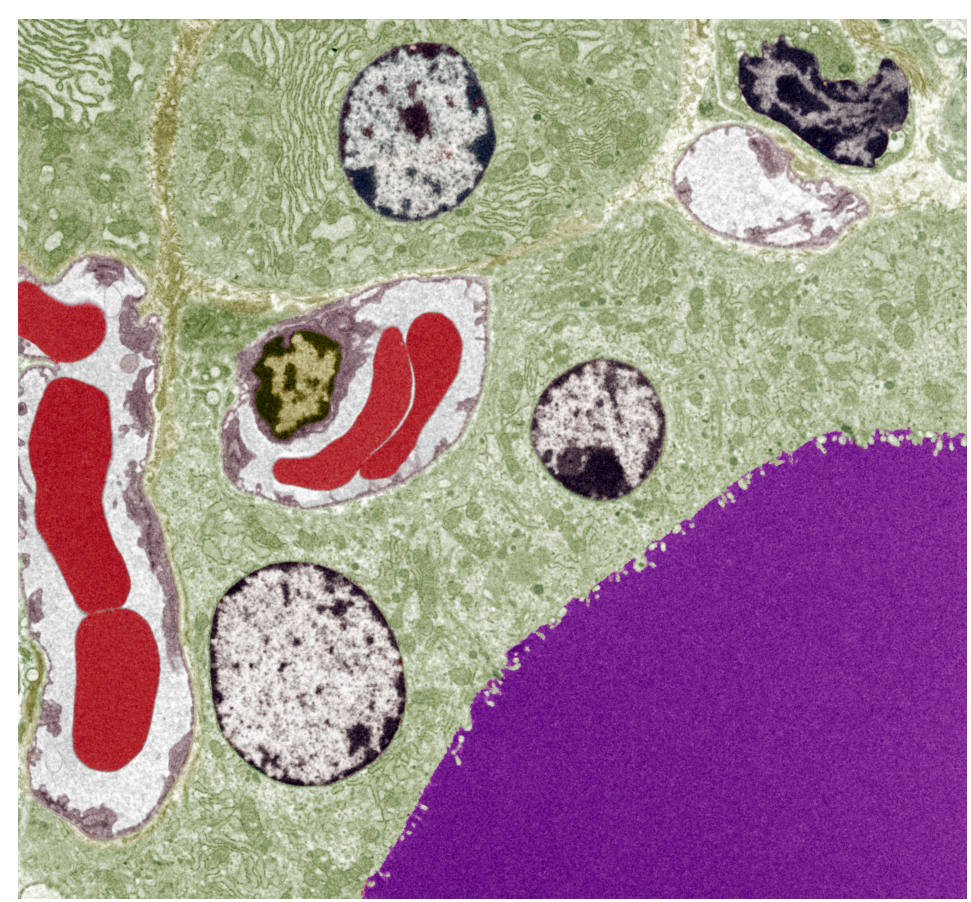

Follikkelcelle i thyreoidea. Lagring av tyroksin skjer i det lilla feltet, de grå og svarte strukturene er cellekjerner. Illustrasjonsfoto: Science Photo Library/NTB scanpix

Tyroksin virker via cellekjernen og aktiverer gener. Genaktiveringen fører til endret proteinsyntese, slik at en doseøkning av hormonet gir merkbare virkninger først etter noen dager. Det virksomme hormonet, trijodotyronin, kan binde seg til to reseptorer i cytoplasma, TR $\alpha$ og TR $\beta$, som begge virker i cellekjernen. TR $\beta$-reseptoren har dessuten raske cytoplasmatiske effekter, mens virkningen av TR $\alpha$-reseptoren på cytoplasmatiske signalveier har vært mer uviss.

En ny studie har kartlagt både cytoplasmatiske og nukleære angrepspunkt for trijodotyronin ved å sammenligne hormonvirkninger i normale mus, knockoutmus og mus med små mutasjonsforandringer i genene for TR $\alpha$ - og TR $\beta$-reseptorene (1). TR-virkning på cellekjernen var nødvendig for den kjente tilbakekoblingsmekanismen mellom thyreoideahormon og hypothalamus/hypofyse, via TR $\beta$-reseptorer, og for skjelettutvikling 
og vekst, via TR $\alpha$-reseptorer. Men viktige virkninger, bl.a. på hjertets slagfrekvens, var uavhengige av kjernesignalering og gikk via $\mathrm{TR} \alpha$-reseptorer på cytoplasmatiske signalveier. Kroppstemperatur, oksygenforbruk, motilitet og senket blodkonsentrasjon av glukose og triglyserider var også avhengige av cytoplasmatisk signalering, via TR $\beta$-reseptorer.

- Selv om det er vesentlige forskjeller i hormonfysiologien mellom artene, gir denne studien svært spennende innsikt i et fenomen som også er kjent hos mennesker, sier Kristian Løvås, som er professor ved Klinisk institutt 2, Universitetet i Bergen. Vi vet at hormoner som bindes til kjernereseptorer, også har raske fysiologiske effekter som ikke kan medieres via regulering av genekspresjon. Betydningen av slik ikke-genomisk regulering hos mennesket er imidlertid lite kjent, men kan vise seg å være mye viktigere enn vi har trodd til nå. Familien av kjernereseptorer er svært stor og er dypt involvert i regulering av metabolske prosesser. Videre innsikt i kjernereseptorenes ikke-genomiske effekter vil sannsynligvis få kliniske implikasjoner hos mennesker, sier Løvås.

\section{LITTERATUR:}

1. Hönes GS, Rakov H, Logan J et al. Noncanonical thyroid hormone signaling mediates cardiometabolic effects in vivo. Proc Natl Acad Sci U S A 2017; 114: E11323 - 32. [PubMed][CrossRef]

Publisert: 17. april 2018. Tidsskr Nor Legeforen. DOI: 10.4045/tidsskr.18.0116

(C) Tidsskrift for Den norske legeforening 2020. Lastet ned fra tidsskriftet.no 